\title{
IMPLEMENTASI KEBIJAKAN PENGISIAN JABATAN PIMPINAN TINGGI PRATAMA MELALUI SELEKSI TERBUKA DI LINGKUNGAN PEMERINTAH KOTA PALANGKA RAYA
}

\author{
The policy Implementation of primary leader position through open selection in the \\ Palangka Raya city government environtment
}

\section{YURIRIN RICHI* \\ BULKANI \\ MITA SARI}

\begin{abstract}
Universitas Muhammadiyah Palangkaraya, Palangka Raya, Central Kalimantan, Indonesia
\end{abstract}

Email : asyifadeichi@gmail.com

\section{Keywords :}

Policy

Implementation

Open Bidding

Environment

Kata Kunci :

Kebijakan

Implementasi

Seleksi Terbuka

Jabatan Pimpinan Tinggi

\begin{abstract}
Abstrak
Penelitian ini berangkat dari fenomena sebagai sebuah sistem yang baru maka kebijakan pelaksanaan seleksi terbuka di lingkungan pemerintah kota Palangka Raya ditanggapi beragam oleh PNS terutama di lingkungan pemerintah kota Palangka Raya dan PNS yang mendaftar sebagai peserta jumlahnya sedikit, tidak sesuai jumlah yang diharapkan sehingga sampai dilakukan perpanjangan masa pendaftaran.
\end{abstract}

Dalam penelitian ini menggunakan pendekatan kualitatif. Data penelitian ini diperoleh dari hasil pengamatan langsung, wawancara, dan mengumpulkan dokumen-dokumen dan menggunakan triangulasi sumber data dan triangulasi teori.

Berdasarkan hasil penelitian bahwa implementasi kebijakan pengisian jabatan pimpinan tinggi pratama melalui seleksi terbuka di lingkungan pemerintah kota Palangka Raya sudah berjalan dengan baik tetapi belum optimal. Rendahnya minat para PNS untuk mengikuti seleksi terbuka dikarenakan ada anggapan bahwa seleksi terbuka hanya formalitas. Kendala yang dihadapi adalah faktor kecenderungan yaitu sikap dan minat dari para PNS yang masih kurang serta faktor sumber daya yaitu fasilitas yang belum memadai sehingga memerlukan biaya yang besar untuk sewa gedung.

Penulis menyarankan pemerintah kota Palangka Raya hendaknya bisa secara aktif dan konsisten serta menjaga komitmen agar kedepannya pelaksanaan seleksi terbuka bisa mendapatkan kepercayaan dan minat dari para PNS, terus berbenah dalam penyediaan dan peningkatan fasilitas sarana dan prasarana seperti gedung, ruang pertemuan, komputer dan perlengkapannya, menggunakan pihak asesor yang sudah terakreditasi oleh Badan Kepegawaian Negara dan untuk tahapan uji kompetensi bisa memanfaatkan hasil talent pool yang dilaksanakan oleh Pusat Penilaian Kompetensi Badan Kepegawaian Negara.

\footnotetext{
Abstract

This research departs from the phenomenons as a new system the policy of implementation of open selection within the palangka raya city government has been responded to by varios civil servant especially in Palangka Raya government environment and civil servants who register as participants does not match the exected amount so that an extention of the registratration period. In this study using a qualitative approach. The research data was obtained from direct observations, interviews and collecting documents and using triangulation of data sources and theory triangulation.

Based on the result of research that the policy implementation of primary leader position through open selection in the Palangka Raya city government environment has been going well but not yet optimal. The low interest of civil servant to participate in open selection is because there is an assumption that open selection is only a formality. The constraints faced are the tendency factor, whish is the attitudes and interest of the civil servant who are still lacking and the resource factor, which is inadequate facilitieas so that it entails a large cost for building rent.

The aouthor suggest that the city government of Palangka Raya should be able to actively and consistenly as well as maintain commitments so that in the future the implementation of open selection can gain the trust and interest of the sivil servants, continue to improve in the provision and improvements of facilies such as building, meeting rooms, computers and equipment, using the assessor who has been accredited by the state personnel agency and for the competency test stage can take advantage of the results of the talent pool conducted by the state personnel board competency assessment center.
}

Published

Oktober 2020 


\section{PENDAHULUAN}

Pengisian jabatan pimpinan tinggi (JPT) secara terbuka merupakan salah satu bentuk kebijakan penerapan sistem merit dalam manajemen ASN. Pengisian ini bertujuan menyelenggarakan seleksi yang transparan, objektif, kompetitif dan akuntabel sehingga terpilihnya calon pejabat pemerintah yang sesuai dengan kompetensi yang dibutuhkan. Seleksi terdiri dari seleksi administratif, uji kompetensi dan penelusuran rekam jejak dilakukan secara objektif dengan menggunakan bantuan lembaga penilai kompetensi (assessor). Seleksi dilakukan secara terbuka dengan mengumumkan secara luas guna memberikan kesempatan kepada seluruh PNS yang memenuhi persyaratan untuk mengikutinya.

Sebagai sebuah sistem yang baru maka kebijakan pelaksanaan seleksi terbuka ini ditanggapi beragam oleh PNS terutama di lingkungan pemerintah kota Palangka Raya. Ada beberapa kalangan yang masih bersikap skeptis, menganggap bahwa ini hanya kegiatan formalitas semata dan sudah adanya "satria piningit" yang dari awal sudah disiapkan oleh pejabat pembina kepegawaian pada jabatan yang dilelang. Pemahaman tadi akhirnya berimbas pada sikap untuk tidak mau mengikuti seleksi terbuka karena hanya membuang waktu, pikiran, tenaga dan biaya.

Hal tadi terbukti setelah dilakukan pembukaan penerimaan seleksi terbuka mulai tanggal 5 Agustus 2019 sampai dengan 19 Agustus 2019 (I5 hari kerja), dari II jabatan yang dilelang terdapat 4 jabatan yang masih kurang peminatnya. Sehingga sesuai ketentuan yang berlaku maka 4 (empat) jabatan tadi harus diperpanjang lagi masa penerimaannya selama 7 (tujuh) hari kerja. Sesuai aturan untuk jabatan yang dilelang maka paling sedikit 3 (tiga) orang pelamar maka bisa untuk dilanjutkan ke tahap seleksi berikutnya.

Masalah lainnya dalam pelaksanaan kebijakan kegiatan seleksi terbuka adalah memakan waktu dan biaya yang tidak sedikit. Mulai dari proses awal kegiatan ini menggunakan biaya untuk honorarium panitia seleksi, honorarium sekretariat, biaya sewa gedung, makan minum kegiatan, makan minum rapat, transportasi akomodasi (tiket pesawat dan hotel) untuk pada panitia seleksi dan assessor dari luar daerah. Disaat situasi dan kondisi APBD Kota Palangka Raya yang belum stabil maka sebenarnya kegiatan ini termasuk kegiatan yang berdana besar.

Berdasarkan pada beberapa permasalahan di atas, maka penulis tertarik untuk menelitii implementasi kebijakan pengisian jabatan pimpinan tinggi pratama melalui seleksi terbuka di lingkungan pemerintah kota Palangka Raya serta apa saja kendala atau hambatan yang dihadapi selama pelaksanaan kegiatan berlangsung.

Hasil penelitian ini juga diharapkan berguna sebagai bahan masukan bagi pemerintah kota Palangka Raya yang berkaitan implementasi pengisian jabatan pimpinan tinggi pratama melalui seleksi terbuka di lingkungan pemerintah kota Palangka Raya.

Penelitian ini bertujuan mengetahui tentang implementasi serta hambatan/kendala yang dihadapi dalam pengisian jabatan pimpinan tinggi pratama melalui seleksi terbuka di lingkungan pemerintah kota Palangka Raya.

Menurut Budi Winarno, implementasi kebijakan merupakan tahap yang krusial dalam proses kebijakan publik. Suatu program kebijakan harus diimplentasikan agar mempunyai dampak atau tujuan yang diinginkan. Implementasi kebijakan dipandang dalam pengertian yang luas merupakan tahapan dari proses kebijakan segera setelah penetapan undangundang, dimana berbagai aktor, organisasi, prosedur dan teknik bekerja bersama-sama untuk menjalankan kebijakan dalam upaya untuk meraih tujuan-tujuan kebijakan atau program-program.

Ripley dan Franklin berpendapat bahwa implementasi adalah apa yang terjadi setelah undangundang ditetapkan yang memberikan otoritas program, kebijakan, keuntungan (benefit) atau suatu jenis luaran yang nyata (tangible output). Istilah implementasi 
menunjuk pada sejumlah kegiatan yang mengikuti pernyataan maksud tentang tujuan program dan hasilhasil yang diinginkan oleh pejabat pemerintah.

Sementara itu Grindle juga memberikan pandangannya tentang implementasi dengan mengatakan bahwa secara umum tugas implementasi adalah membentuk suatu kaitan (linkage) yang memudahkan tujuan-tujuan kebijakan bisa di realisasikan sebagai dampak dari suatu kegiatan pemerintah. Dengan demikian, berbagai program bisa dikembangkan untuk merespon tujuan kebijakan yang sama. Programprogram tindakan itu bisa dipilah kedalam proyekproyek yang spesifik untuk dikelola. Maksud dari program-program tindakan dan proyek individu adalah untuk mendatangkan suatu perubahan dalam lingkungan kebijakan suatu perubahan yang bisa diartikan sebagai dampak dari suatu program.

Selanjutnya, Van Meter dan Van Horn membatasi implementasi kebijakan sebagai tindakantindakan yang dilakukan oleh individu-indivivdu (atau kelompok-kelompok) pemerintah maupun swasta yang diarahkan untuk emncapai tujuan-tujuan yang telah ditetapkan dalam keputusan-keputusan kebijakan sebelumnya. Tindakan-tindakan ini mencakup usahausaha untuk mengubah keputusan-keputusan menjadi tindakan-tindakan operasional dalam kurun waktu tertentu maupun dalam rangka melanjutkan usaha-usaha untuk mencapai perubahan-perubahan besar dan kecil yang ditetapkan oleh keputusan-keputusan kebijakan.

Edward membicarakan empat faktor atau variabel krusial dalam implementasi kebijakan publik, yaitu komunikasi, sumber-sumber, kecenderungankecenderungan atau tingkah laku-tingkah laku dan struktur birokrasi. Patut diperhatikan disini bahwa implementasi dari setiap kebijakan merupakan suatu proses yang dinamis yang mencakup banyak interaksi dari banyak variabel. Oleh karena itu, tidak ada variabel tunggal dalam proses implementasi, sehingga perlu dijelaskan keterkaitan antara satu variabel dengan variabel yang lain, dan bagaimana variabel-variabel ini mempengaruhi proses implementasi.

\section{a. Komunikasi}

Secara umum Edward membahas tiga hal penting dalam proses komunikasi kebijakan yaitu transmisi, konsistensi dan kejelasan (clearity). Menurut Edward, persyaratan pertama bagi implementasi kebijakan yang efektif adalah bahwa mereka yang melaksanakan keputusan harus mengetahui apa yang harus mereka lakukan. Jika kebijakan-kebijakan ingin diimplementasikan sebagaimana mestinya, maka petunjuk-petunjuk pelaksanaan tidak hanya harus dipahami, melainkan juga petunjuk-petunjuk itu harus jelas.

\section{b. Sumber-sumber}

Perintah-perintah implementasi mungkin diteruskan secara cermat, jelas dan konsisten, tetapi jika para pelaksana kekurangan sumber-sumber yang diperlukan untuk melaksanakan kebijakan-kebijakan, maka implemntasi inipun cenderung tidak efektif. Dengan demikian, sumber-sumber dapat merupakan faktor yang penting dalam melaksanakan kebijakan publik. Sumber-sumber yang penting meliputi : staf yang memadai serta keahlian-keahlian yang baik untuk melaksanakan tugas-tugas mereka, Informasi, wewenang dan fasilits-fasilitas yang diperlukan untuk menerjemahkan usul-usul diatas kertas guna melaksanakan pelayanan-pelayanan publik.

\section{c. Kecenderungan-kecenderungan}

Kecenderungan dari para pelaksana kebijakan merupakan faktor ketiga yang mempunyai konsekuensi-konsekuensi penting bagi implementasi kebijakan yang efektif. Jika para pelaksana bersikap baik terhadap suatu kebijakan tertentu dan hal ini berarti adanya dukungan, kemungkinan besar mereka melaksanakan kebijakan sebagaimana yang diinginkan oleh para pembuat keputusan awal. Demikian juga sebaliknya, bila tingkah laku atau perspektif para pelaksana berbeda dengan para pembuat keputusan 
maka proses pelaksanaan suatu kebijakan akan menjadi semakin sulit.

\section{d. Struktur Birokrasi}

Birokrasi merupakan salah satu badan yang paling sering bahkan secara keseluruhan menjadi pelaksana kebijakan. Struktur organisasi-organisasi yang melaksanakan kebijakan memiliki pengaruh penting pada implementasi. Salah satu aspek struktural paling dasar dari suatu organisasi adalah prosedurprosedur kerja ukuran dasarnya (Standard Operating System, SOP). Prosedur-prosedur biasa ini dalam menanggulangi keadaan-keadaan umum digunakan dalam organisasi-organisasi public dan swasta. Dengan menunggunakan SOP, para pelaksana dapat memanfaatkan waktu yang tersedia. Selain itu, SOP juga menyeragamkan tindakan-tindakan dari para pejabat dalam organisasi-organisasi kompleks dan tersebar luas, yang pada gilirannya dapat menimbulkan fleksibilitas yang besar, dan kesamaan yang besar dalam penerapan peraturan-peraturan.

\section{METODOLOGI}

Dalam penelitian ini pendekatan yang digunakan adalah pendekatan kualitatif karena penelitian yang dilakukan ini berusaha mengetahui, menjelaskan dan menganalisis secara mendalam gejalagejala yang berkaitan dengan kebijakan pemerintah dan tidak mungkin di ukur secara tepat. Seperti pendapat dari Judistira K. Garna (1999: 32) menjelaskan pendekatan kualitatif dicirikan oleh tujuan penelitian yang berupaya guna memahami gejala-gejala yang sedemikian rupa tak memerlukan kuantifikasi atau karena gejala-gejala tersebut tak memungkinkan diukur secara tepat.

Nazir (2003:I74) menerangkan pengumpulan data adalah prosedur yang sistematis dan standar untuk memperoleh data yang diperlukan. Selalu ada hubungan antara metode mengumpulkan data dengan masalah penelitian yang ingin di pecahkan. Masalah memberi arah dan mempengaruhi metode pengumpulan data. Banyak masalah yang dirumuskan tidak akan bisa dipecahkan karena metode untuk memperoleh data yang digunakan tidak memungkinkan, ataupun metode yang ada tidak dapat menghasilkan data seperti yang di inginkan. Dalam penelitian ini, teknik pengumpulan data yang digunakan peneliti adalah interview (wawancara), observasi, dan dokumentasi.

Nazir (2003 : 346) menyatakan bahwa : "analisis data adalah mengelompokkan, membuat suatu urutan, memanipulasi data serta menyingkat data sehingga mudah untuk dibaca". Jadi analisa data merupakan proses penyusunan data berarti pengelompokan data dalam pola, tema atau kategori. Langkah-langkah yang dilakukan dalam menganalisis data dalam penelitian ini adalah reduksi data, penyajian data, dan penarikan kesimpulan.

Dalam penelitian ini triangulasi yang digunakan yaitu triangulasi sumber data dan triangulasi teori. Sampai data lengkap kemudian divalidasi dari berbagai sumber sehingga menjadi dasar untuk penarikan kesimpulan. Dengan teknik ini diharapkan data yang dikumpulkan memenuhi konstruk penarikan kesimpulan dan layak untuk dimanfaatkan.

\section{HASIL DAN PEMBAHASAN}

Sejak dikeluarkannya Undang-undang Nomor 5 Tahun 2014 tentang Aparatur Sipil Negara yang mengamatkan bahwa pengisian jabatan pimpinan tinggi baik pada instansi pusat dan instansi daerah dilakukan secara terbuka dan kompetitif di kalangan PNS dengan memperhatikan syarat kompetensi, kualifikasi, kepangkatan, pendidikan dan pelatihan, rekam jejak dan integritas serta persyaratan lain yang dibutuhkan sesuai dengan ketentuan peraturan perundang-undangan dan dilakukan pada tingkat nasional.

Kebijakan tadi ditindaklanjuti oleh pemerintah kota Palangka Raya dengan mulai melaksanakan seleksi terbuka pertama kali pada tahun 2017 untuk pengisian jabatan pimpinan tinggi pratama untuk jabatan sekretaris daerah. Dan pada tahun 2019 kembali melaksanakan 
seleksi terbuka untuk pengisian II (sebelas) jabatan pimpinan tinggi pratama yang lowong setingkat eselon II.b.

Berdasarkan hasil penelitian dapat diketahui bahwa pelaksanaan implementasi kebijakan pengisian jabatan pimpinan tinggi pratama melalui seleksi terbuka di lingkungan pemerintah kota Palangka Raya dimulai dengan pengajuan proposal seleksi terbuka melalui surat Walikota Palangka Raya Nomor : 870/101.aBANG/BKPP/VI/2019 tanggal 25 Juni 2019 perihal persetujuan pelaksanaan seleksi terbuka jabatan pimpinan tinggi pratama di lingkungan pemerintah kota Palangka Raya tahun 2019 dan ditindaklanjuti dengan terbitnya surat dari Ketua Komisi Aparatur Sipil Negara Nomor : B-2540/KASN/8/2019 tanggal 2 Agustus 2019 hal rekomendasi rencana seleksi terbuka JPT Pratama di lingkungan kota Palangka Raya.

Implementasi kebijakan pengisian jabatan pimpinan tinggi pratama melalui seleksi terbuka di lingkungan pemerintah kota Palangka Raya dilaksanakan tanggal 7 Agustus sampai dengan 17 September 2019 diikuti oleh 53 (lima puluh tiga) orang peserta yang terdiri dari I (orang) PNS dari pemerintah kabupaten Kapuas, 4 (empat) orang PNS dari pemerintah provinsi Kalimantan Tengah dan 48 (empat puluh delapan) PNS dari pemerintah kota Palangka Raya. Jumlah pelamar tadi setelah terjadi perpanjangan penerimaan seleksi terbuka yang pada penerimaan pertama selama 15 (lima belas) hari kerja masih terdapat jabatan yang jumlah pesertanya tidak memenuhi ketentuan minimal sehingga apabila ingin meneruskan ke tahap seleksi selanjutnya harus memperpanjang waktu penerimaan selama 7 (tujuh hari).

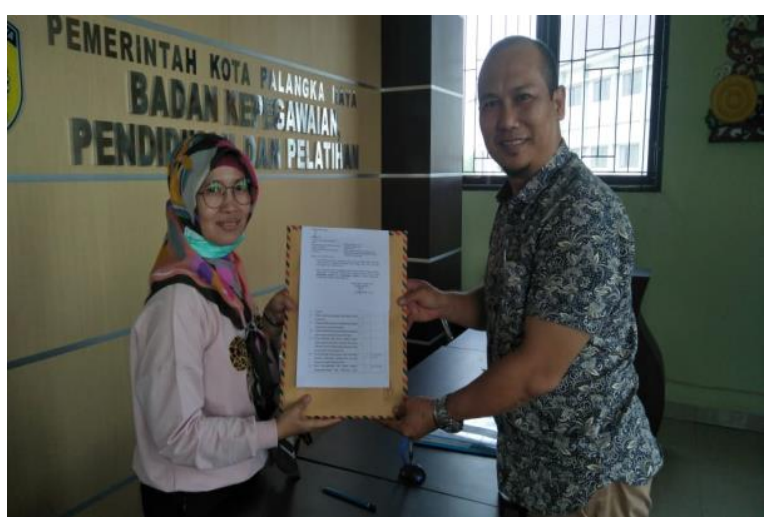

Gambar I Sekretariat Panitia menerima berkas peserta dari Kabupaten Kapuas

Kurangnya jumlah peserta pada penerimaan awal berpengaruh pada keputusan selanjutnya apakah jabatan yang lowong tadi bisa tetap diisi atau tidak. Karena bila peserta dari satu jabatan yang akan diseleksi kurang dari 3 (tiga) peserta maka sesuai aturan tidak dapat dilanjutkan ke tahapan seleksi selanjutnya. Melihat hasil dan perkembangan serta laporan dari tim pemeriksa berkas maka panitia seleksi memutuskan untuk memperpanjang penerimaan seleksi terbuka dengan harapan agar para PNS yang memenuhi persyaratan bisa mendaftar sebagai peserta seleksi terbuka sehingga bisa menambah jumlah peserta dari setiap jabatan yang dilelang. Keputusan panitia seleksi untuk memperpanjang penerimaan ini sudah sesuai dengan aturan dan sudah dikonsultasikan serta dilaporkan kepada pihak Komisi Aparatur Sipil Negara.

Berdasarkan informasi yang didapatkan dapat diketahui panitia seleksi mengolah hasil dan membuat pengumuman dari setiap tahapan seleksi kepada para peserta, dari tahapan seleksi administrasi, tahapan seleksi uji kompetensi, tahapan seleksi tes tertulis hingga tahapan tes kesehatan dan kejiwaan. Tugas panitia seleksi selanjutnya adalah mengajukan 3 (tiga) nama dari setiap jabatan yang dilelang kepada pejabat pembina kepegawaian serta dilaporakan kepada Komisi Aparatur Sipil Negara. Pejabat pembina kepegawaian diberikan kewenangan untuk memilih I( satu) nama dari 3 (tiga) nama yang diajukan tadi untuk dilantik sebagai pejabat definitif. Nama yang dipilih harus sesuai dengan namanama yang diajukan tercantum dalam rekomendasi hasil seleksi terbuka dari Komisi Aparatur Sipil Negara. 
Tahapan akhir dalam seleksi terbuka adalah monitoring dan evaluasi. Pejabat pembina kepegawaian melaporkan pelaksanaan seleksi terbuka kepada Komisi Aparatur Sipil Negara melalui surat walikota Palangka Raya Nomor : 870/I45-BANG/BKPP/XI/2019 tanggal 18 September 2019 perihal persetujuan rekomendasi penetapan pejabat pimpinan tinggi pratama di llingkungan pemerintah Kota Palangka Raya dengan melampirkan surat dari ketua panitia seleksi JPT Pratama Kota Palangka Raya Nomor 12 /Pansel.PKY/IX/2019 Tanggal 17 September 2019 tentang pengumuman hasil keseluruhan seleksi terbuka pengisian jabatan pimpinan tinggi pratama di lingkungan pemerintah kota Palangka Raya dan laporan ketua panitia seleksi nomor I3/Pansel.PKY/IX/2019 tanggal I8 September 2019 tentang kegiatan seleksi terbuka JPT Pratama di lingkungan pemerintah kota Palangka Raya dan dengan terbitnya rekomendasi hasil seleksi terbuka jabatan pimpinan tinggi pratama di lingkungan pemerintah kota Palangka Raya dari Komisi Aparatur Sipil Negara Nomor B-3087/KASN/9/2019 Tanggal 20 September 2019 maka dapat disimpulkan bahwa setelah dilakukan evaluasi terhadap kelengkapan laporan hasil seleksi terbuka pada prinsipnya Komisi Aparatur Sipil Negara dapat menyetujui karena telah menggambarkan proses tahapan pelaksanaan seleksi terbuka dengan lengkap.

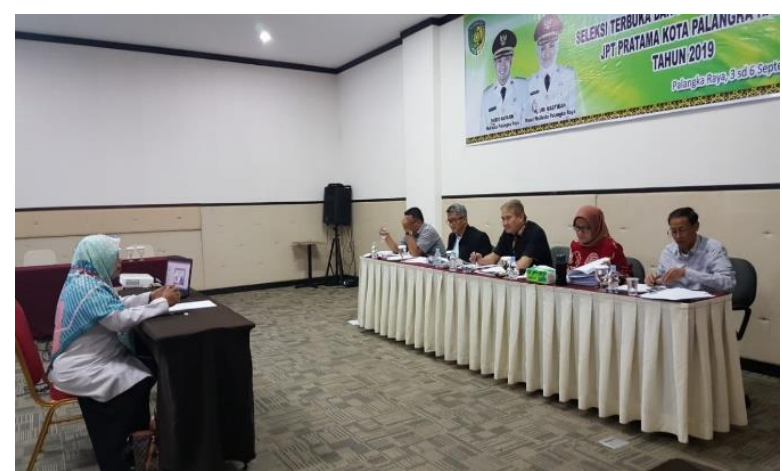

Gambar 2 Pelaksanaan wawancara akhir peserta seleksi terbuka

Menurut Edward, faktor-faktor yang berpengaruh terhadap implementasi kebijakan bekerja secara simultan dan berinteraksi satu sama lain untuk membantu dan menghambat implementasi kebijakan, maka pendekatan yang ideal adalah dengan cara merefleksikan kompleksitas ini dengan membahas semua faktor tersebut sekaligus.

a. Komunikasi

Keputusan-keputusan kebijakan dan perintahperintah harus diteruskan kepada personil yang tepat sebelum dapat diikuti. Tentu saja komunikasi harus akurat dan harus dimengerti dengan cermat oleh para pelaksana. Akan tetapi banyak hambatanhambatan yang menghadang transmisi komunikasi pelaksanaan dan hambatan ini mungkin menghalangi pelaksanaan kebijakan.

Beberapa aspek dari komunikasi ini menurut Edward adalah

I) Transmisi (penyaluran komunikasi yang baik).

Keputusan -keputusan kebijakan dan perintah-perintah harus di teruskan kepada personil yang tepat sebelum keputusankeputusan dan perintah-perintah itu dapat di ikuti.

Berdasarkan hasil penelitian dapat diketahui bahwa Badan Kepegawaian dan Pengembangan Sumber Daya Manusia kota Palangka Raya sudah menyampaikan informasi kepada seluruh PNS yang ada di Lingkungan Pemerintah Kota Palangka Raya baik itu melalui media cetak dan media elektronik. Pengumuman tadi sudah dicantumkan dalam Website resmi BKPSDM, dicetak di koran dan sudah disampaikan secara berjenjang dari pimpinan kepada PNS dibawahnya. 


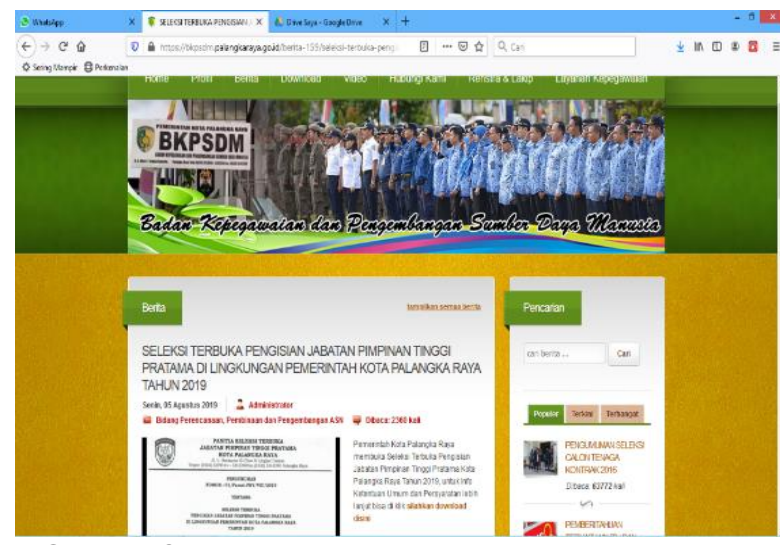

Gambar 3 Tampilan pengumuman seleksi terbuka di website resmi BKPSDM Kota Palangka Raya

2) Kejelasan

Seringkali instruksi-instruksi yang diteruskan kepada pelaksana kabur dan tidak menetapkan kapan dan bagaimana suatu program dilaksanakan. Ketidakjelasan pesan komunikasi yang disampaikan berkenaan dengan implementasi kebijakan akan mendorong interpretasi yang salah bahkan mungkin bertentangan dengan makna pesan awal. Namun demikian, ketidakjelasan pesan komunikasi kebijakan tidak selalu menghalangi implementasi. Pada tataran tertentu para pelaksana membutuhkan fleksibilitas dalam melaksanakan kebijakan.

Menurut hasil penelitian didapat bahwa informasi mengenai Seleksi Terbuka yang disampaikan oleh Badan Kepegawaian dan Pengembangan Sumber Daya Manusia kota Palangka Raya telah disampaikan dengan jelas, mengenai persyaratan, jangka waktu penerimaan serta ketentuan lainnya tercantum jelas dalam pengumuman resmi di website resmi BKPSDM, dan di media cetak. Hambatan muncul dari anggapan PNS itu sendiri yang berfikir bahwa pelaksanaan Seleksi Terbuka ini hanya formalitas dan sudah di atur sedemikian rupa sehingga sudah ada calon yang akan dipilih.
3) Konsistensi

Perintah-perintah yang disampaikan kepada pelaksana harus mempunyai kejelasan dan tidak bertentangan sehingga akan memudahkan para pelaksana untuk menjalankan tugasnya dengan baik. Bila kebijakan tidak jelas dan bertentangan maka akan berakibat pada ketidakefektifan implementasi kebijakan karena tindakan yang sangat longgar besar kemungkinan tidak dapat digunakan untuk melaksanakan tujuan-tujuan kebijakan.

Menurut hasil penelitian didapat bahwa informasi yang telah disampaikan oleh Badan Kepegawaian dan Pengembangan Sumber Daya Manusia kota Palangka Raya sudah konsisten dan tidak berubah-rubah. Informasi yang berbentuk pengumuman resmi tidak membingungkan pihak-pihak terkait.

b. Sumber-sumber

Barangkali sumber yang paling penting dalam melaksanakan kebijakan adalah staf. Ada satu hal yang harus diingat adalah bahwa jumlah tidak selalu mempunyai efek positif bagi implementasi kebijakan. Hal ini berarti bahwa jumlah staf yang banyak tidak secara otomatis mendorong implementasi yang berhasil. Para pelaksana juga harus memiliki ketrampilan-keterampilan yang diperlukan dalam melaksanakan pekerjaan.

Sesuai hasil penelitian yang diperoleh bahwa secara umum staf yang menangani Seleksi Terbuka pada Badan Kepegawaian dan Pengembangan Sumber Daya Manusia kota Palangka Raya sudah memadai dan memiliki kompetensi yang cukup dalam pelaksanaannya. Begitu pula dengan panitia seleksi yang berjumlah 5 (lima) orang, diketuai olah sekretaris daerah kota Palangka Raya, dan anggota I (satu) orang inspektur provinsi Kalimantan Tengah dan I (orang) asisten administrasi umum sekretaris daerah Kota Palangka Raya serta 2 (dua) 
orang diantaranya adalah akademisi profesional dari perguruan tinggi nasional. Demikian pula dengan tim asesmen yang digunakan adalah dari unit psikologi universitas nasional yang sudah memiliki pengalaman dan profesional di bidangnya. Informasi merupakan sumber penting kedua dalam implementasi kebijakan. Informasi mempunyai 2 (dua) bentuk. Pertama informasi mengenai bagaimana melaksanakan suatu kebijakan. Para pelaksana perlu mengetahui apa yang dilakukan dan bagaimana mereka harus melakukannya. Dengan demikian pelaksana harus diberikan petunjuk untuk melaksanakan kebijakan. Bentuk kedua adalah data tentang ketaatan personil-personil lain terhadap PeraturanPeraturan Pemerintah. Pelaksana harus mengetahui apakah orang lain yang terlibat dalam pelaksanaan kebijakan menaati undang-undang atau tidak.

Menurut hasil penelitian dapat diketahui bahwa informasi mengenai bagaimana pelaksana melaksanakan kebijakan tadi sudah memadai dengan adanya Surat Keputusan Walikota Palangka Raya Nomor 188.45/370/2019 tentang pembentukan panitia seleksi terbuka jabatan pimpinan tinggi pratama di lingkungan pemerintah kota Palangka Raya, dan Surat Keputusan Walikota Palangka Raya Nomor 188.45/37I/2019 tentang pembentukan sekretariat panitia seleksi terbuka jabatan pimpinan tinggi pratama di lingkungan pemerintah kota Palangka Raya.

Sumber lain yang penting dalam implementasi adalah wewenang. Kurangnya wewenang yang efektif disadari oleh para pejabat dan karena itu mereka membutuhkan kerjasama dengan pelaksana-pelaksana lain jika ingin program-program dengan berhasil. Wewenang yang memadai seringkali langka terutama dalam mengatur personil-personil lain.
Menurut hasil penelitian dapat diketahui bahwa sumber wewenang dalam implementasi seleksi terbuka sudah memadai yaitu bekerja sama untuk pelaksanaan tes asesemen dan juga untuk pelaksanaan tes kesehatan dan kejiwaan.

Fasilitas fisik bisa pula merupakan sumber-sumber penting dari implementasi. Seorang pelaksana mungkin memiliki staf yang memadai, mungkin memahami apa yang harus dilakukan dan mungkin mempunyai kewenangan untuk melakukan tugasnya, tetapi tanpa bangunan sebagai kantor untuk melaksanakan koordinasi, tanpa perlengkapan, tanpa perbekalan maka besar kemungkinan imlementasi yang direncanakan tidak akan berhasil.

Menurut hasil penelitian dapat diketahui bahwa untuk fasilitas fisik kantor sudah memadai untuk proses administrasi perkantoran saja. Hambatan yang dialami oleh Badan Kepegawaian dan Pengembangan Sumber Daya Manusia belum memiliki ruangan yang representative serta memelukan meja dan kursi untuk tahapan tes asesmen serta penulisan makalah untuk pelaksanaan seleksi terbuka. Sehingga semua tahapan seleksi diadakan di luar kantor dengan biaya sewa.

c. Kecenderungan-kecenderungan

Ada kebijakan yang dilaksanakan secara efektif karena mendapat dukungan dari para pelaksana kebijakan, namun kebijakan-kebijakan lain mungkin akan bertentangan secara langsung dengan pandangan-pandangan pelaksana kebijakan atau kepentingan-kepentingan pribadi atau organisasi dari para pelaksana.

Sesuai hasil penelitian dapat diketahui bahwa kebijakan pengisian jabatan pimpinan tinggi pratama melalui seleksi terbuka di lingkungan pemerintah kota Palangka Raya mendapatkan dukungan dari pihak-pihak terkait terutama dari Walikota dan Wakil Walikota. Para pelaksana dari 
Badan Kepegawaian dan Pengembangan Sumber Daya Manusia Kota Palangka Raya selaku sekretariat panitia seleksi juga mendukung dengan melaksanakan seluruh tahapan seleksi dengan baik. Begitu juga dari panitia seleksi yang berkomitmen dengan menandatangani surat kesediaan menjadi panitia seleksi dan pakta integritas yang akan menyelesaikan semua tahapan seleksi sampai dengan tahapan akhir.

Hanya yang menjadi penghambat yaitu dukungan, minat dan kemauan dari para PNS untuk mengikuti seleksi terbuka yang dirasa masih belum sesuai yang diharapkan. Sehingga seleksi terbuka secara kompetitif belum dirasakan secara maksimal karena jumlah peserta yang sedikit.

d. Struktur Birokrasi

Menurut hasil penelitian dapat diketahui bahwa dalam implementasi kebijakan pengisian jabatan pimpinan tinggi pratama melalui seleksi terbuka di lingkungan pemerintah kota Palangka Raya memiliki SOP dalam bentuk formal Peraturan Walikota Palangka Raya Nomor I5 Tahun 2016 tentang pedoman pelaksanaan seleksi terbuka di lingkungan pemerintah kota Palangka Raya tetapi masih mengacu pada Peraturan Menteri Pendayagunaan Aparatur Negara dan Reformasi Birokrasi Nomor 13 Tahun 2014.

Dari segi fragmentasi yang bertujuan menyebarkan tanggung jawab, Badan Kepegawaian dan Pengembangan Sumber Daya Manusia Kota Palangka Raya memiliki tugas dan tanggung jawab sesuai dengan Peraturan Walikota Palangka Raya Nomor 58 Tahun 2019 tentang Kedudukan, Susunan Organisasi, Tugas, Fungsi dan Tata Kerja Badan Kepegawaian dan Pengembangan Sumber Daya Manusia Kota Palangka Raya. Seleksi terbuka merupakan salah satu dari uraian tugas kepala bidang penilaian kinerja, pengembangan karir dan pembinaan aparatur dan diturunkan lagi ke uraian tugas kepala sub bidang analisa pengembangan karir dan penempatan jabatan ASN.

Dalam pelaksanaannya banyak dari pegawai yang ada di Badan Kepegawaian dan Pengembangan Sumber Daya Manusia Kota Palangka Raya yang ikut terlibat dan turut membantu selaku anggota sekretariat panitia seleksi. Badan Kepegawaian dan Pengembangan Sumber Daya Manusia Kota Palangka Raya selaku implementor sudah melakukan fragmentasi dalam implementasi sesuai dengan tugas dan fungsinya masing-masing.

Dari berbagai uraian diatas dapat diketahui bahwa implementasi kebijakan pengisian jabatan pimpinan tinggi pratama melalui seleksi terbuka di lingkungan pemerintah kota Palangka Raya sudah berjalan dengan baik tetapi belum optimal. Badan kepegawaian dan pengembangan sumber daya manusia kota Palangka Raya sebagai salah satu implementor sudah menjalankan kebijakan pengisian jabatan pimpinan tinggi pratama melalui seleksi terbuka di lingkungan pemerintah kota Palangka Raya sesuai dengan aturan dan ketentuan yang berlaku.

Rendahnya minat para PNS untuk mengikuti seleksi terbuka dikarenakan ada anggapan bahwa seleksi terbuka hanya formalitas, karena sudah ada yang dicalonkan untuk menjabat dijabatan yang akan diisi dan apabila ikut sebagai peserta maka hanya akan membuang waktu, hanya akan menjadi pelengkap agar jabatan yang akan diisi tadi bisa diisi oleh calon yang sudah disiapkan. Hal ini tentunya dikarenakan karena ketentuan bahwa 3 (tiga) besar dari setiap jabatan yang dilelang maka akan dipilih oleh pejabat pembina kepegawaian untuk dilantik sebagai pejabat definitif. Ketentuan inilah yang mempengaruhi mindset dari banyak PNS bahwa pada akhirnya akan tetap kembali lagi kepada pejabat pembina kepegawaian untuk memutuskan siapa yang akan didefinitifkan. Hal ini 
sesuai dengan ketentuan Undang-undang Nomor 5 Tahun 2014 tentang Aparatur Sipil Negara pasal II5 ayat (4), pejabat pembina kepegawaian memilih I (satu) dari 3 (tiga) nama calon pejabat pimpinan tinggi pratama yang terpilih untuk ditetapkan dan dilantik sebagai pejabat pimpinan tinggl pratama dengan catatan memperhatikan persyaratan dan ketentuan peraturan perundangundangan yang berlaku.

Badan kepegawaian dan pengembangan manusia sudah berupaya dalam mengatasi hambatan terkait sedikitnya jumlah peserta yaitu dengan berkomunikasi secara aktif kepada para PNS di lingkungan pemerintah kota Palangka Raya bahwa proses seleksi terbuka ini akan dilaksanakan sesuai dengan aturan, panitia seleksi, sekretariat, dan tim asesmen semuanya akan profesioal sesuai dengan tugasnya masing-masing. Tidak ada yang berkepentingan dengan peserta, semuanya seusai dengan peraturan yang berlaku.

Implementasi kebijakan pengisian jabatan pimpinan tinggi pratama melalui seleksi terbuka di lingkungan pemerintah Kota Palangka Raya merupakan wujud dari konsep kebijakan publik untuk memecahkan masalah publik terkait dengan pemilihan pejabat yang memiliki kompetensi sesuai dengan kebutuhan organisasi dan sistem merit yang merupakan amanat dari Undang-Undang Nomor 5 Tahun 2014 Tentang Aparatur Sipil Negara.

\section{KESIMPULAN}

I. Implementasi kebijakan pengisian jabatan pimpinan tinggi pratama melalui seleksi terbuka di lingkungan pemerintah kota Palangka Raya sudah berjalan dengan baik tetapi belum optimal. Rendahnya minat para PNS untuk mengikuti seleksi terbuka dikarenakan ada anggapan bahwa seleksi terbuka hanya formalitas, karena sudah ada yang dicalonkan untuk menjabat di jabatan yang akan diisi dan apabila ikut sebagai peserta maka hanya akan membuang waktu, hanya akan menjadi pelengkap agar jabatan yang akan diisi tadi bisa diisi oleh calon yang sudah disiapkan.

2. Hambatan dalam implementasi kebijakan pengisian jabatan pimpinan tinggi pratama di lingkungan pemerintah kota Palangka Raya adalah :

a) Faktor kecenderungan, hambatan yang dihadapi adalah memang peserta yang sedikit dikarenakan minat yang kurang, ada anggapan dikalangan PNS bahwa proses seleksi terbuka ini hanya formalitas saja. Dukungan, minat dan kemauan dari para PNS untuk mengikuti seleksi terbuka yang dirasa masih belum sesuai yang diharapkan. Sehingga seleksi terbuka secara kompetitif belum dirasakan secara maksimal karena jumlah peserta yang sedikit.

b) Faktor Sumber Daya, hambatan yang dialami oleh Badan Kepegawaian dan Pengembangan Sumber Daya Manusia belum memiliki fasilitas ruangan yang representatif serta memerlukan meja dan kursi untuk tahapan tes asesmen serta penulisan makalah untuk pelaksanaan seleksi terbuka. Sehingga semua tahapan seleksi diadakan di luar kantor dengan biaya sewa.

\section{SARAN}

Berdasarkan hasil kesimpulan diatas, maka dapat diberikan beberapa saran yang diharapkan dapat berkontribusi dalam penyelenggaran seleksi terbuka di lingkungan pemerintah kota Palangka Raya dimasa yang akan datang, yaitu:

I. Pemerintah kota Palangka Raya hendaknya bisa secara aktif dan konsisten serta menjaga komitmen agar kedepannya pelaksanaan seleksi terbuka bisa mendapatkan kepercayaan dan minat dari para PNS.

2. Pemerintah kota Palangka Raya bisa terus berbenah dalam penyediaan dan peningkatan fasilitas sarana dan prasarana seperti gedung, ruang pertemuan, komputer dan perlengkapannya. 
3. Pemerintah kota Palangka Raya hendaknya menggunakan pihak asesor yang sudah terakreditasi oleh BKN sesuai dengan apa yang diamanatkan dalam peraturan perundangundangan dan untuk tahapan uji kompetensi hendaknya bisa memanfaatkan hasil talent pool yang dilaksanakan oleh Pusat Penilaian Kompetensi Badan Kepegawaian Negara yang hasil penilaiannya berlaku hingga 2 (dua) tahun.

\section{REFERENSI}

Agung Nugraha, 2017. Implementasi Seleksi Terbuka pada pengisian Jabatan Pimpinan Tinggi Pratama di Lingkungan Pemerintah Kota Bukittinggi, Institut Pemerintahan Dalam Negeri.

Arikunto, Suharsimi, 2006, Prosedur Penelitian Suatu Pendekatan Praktek, PT. Rineka Cipta, Jakarta.

Garna K, Judistira, 2000, Metoda Penelitian Sosial Penelitian dalam Ilmu Pemerintahan, Primaco Akademika, Bandung.

Idrus, Muhammad, 2009, Metode Penelitian Ilmu Sosial Pendekatan Kualitatif dan Kuantitatif, Erlangga, Jakarta.

Luankali, Bernadus. 2007. Analisis Kebijakan Publik Dalam Proses Pengambilan Keputusan, Amelia Press.

Moleong, Lexy. 2007. Metode Penelitian Kualitatif, Remaja Rosdakarya Bandung.

Munawir Sazjali, 2019. Implementasi Seleksi Terbuka Jabatan Pimpinan Tinggi di Kabupaten Tana Tidung, Universitas Terbuka.

Nasir, 2019. Implementasi Kebijakan Seleksi Terbuka dalam pengisian Jabatan Pimpinan Tinggi Pratama di Lingkup Pemerintahan Kabupaten Toraja Utara, Polikteknik Informatika Nasional.

Nazir, 20I I. Metodologi Penelitian, Ghalia Indonesia

Nirmala Krishna Dewi, 2017. Mekanisme Pengisian Jabatan Pimpinan Tinggi Pratama melalui Seleksi Terbuka di Kabupaten Kubu Raya, Universitas Gadjah Mada.

Rahardjo, Mudjia. 2010. Triangulasi dalam Penelitian Kualitatif, https://mudjiarahardjo.uin-malang.ac.id/materikuliah/270-triangulasi-dalam-penelitian-kualitatif.html.

Sugiyono. 2013. Metodologi Penelitian Kombinasi, Alfabeta Bandung.

Umar, Husein, 2008, Riset Sumber Daya Manusia Dalam Organisasi, PT. Gramedia Pustaka Utama, Jakarta.
Winarno, Budi. 2007. Kebijakan Publik Teori dan Proses, Media Pressindo.

Wibawa, Samodra. 1994. Evaluasi Kebijakan Publik, PT. RajaGrafindo Persada.

Yousa, 2007. Kebijakan Publik Teori dan Proses, Lembaga Pengkajian Penelitian dan Pengembangan Administrasi Negara. 